\title{
The Perception of Induction System on Headteachers and Assistance on Public Basic School in West Mamprusi Municipality in the Northeast Region of Ghana
}

\author{
Mohammed Mutala Surazu \\ Walewale Senior High School
}

\begin{abstract}
The study was conducted to investigate the perception of induction system on public basic schools in the West Mamprusi Municipal in the Northeast Region. The objectives of the study were to find out some of the training and induction programs that are organized in basic schools in the study area, determine the causes of ineffective induction programs organized in basic schools in the study area and to ascertain the perception of induction programs on teaching and learning in basic schools in the study area. The researcher used descriptive survey design to collect quantitative data for the study. The targeted population was one hundred and twenty 120 head teachers and assistant head teachers of the public basic schools in the West Mamprusi Municipality. Based on the findings, some other induction programs organized in some of the schools include; training on the use of methodologies in teaching, training on guidance and mentoring new teachers, training on school and community relationship, health and safety training, training on GES code of ethics and training on lesson plan preparation. Based on the findings it can be concluded that induction programs supports and mitigates teacher attrition, increases career commitment, and contributes to retention through meeting teachers' personal and professional needs which also include improvement in professional growth and development, effective integration of new employees to the organization and providing new teachers with training tools and Other needs. Also working conditions play a significant role in teacher career satisfaction and commitment as the findings depicted.
\end{abstract}

\section{Keywords: "Perception", "Induction", "System", "Head-teacher" , " Public", "Basic"}

\section{Introduction:}

Basic School heads succeed in improving access and quality of education service once they are able to plan and manage a good cordial relationship among their staff and beyond and this has always been a key issue in education in the West Mamprusi Municipality and the country as a whole. The teacher plays an important role in the functioning of the school and also imparting knowledge.

According to Pollard (2005) welcoming and integrating a new member of staff is part of those vital first impressions termed as induction. To Pollard induction might even work for experienced teachers who are abreast with the school's style and priorities. She said that induction does not necessarily mean training but just taking them through how your school functions. Pollard (2005) further posits that induction help new members to fit into an existing unit already established in the school that is solid and well-formed. Therefore, there is the need to cultivate the feeling that the new members of staff fit in and feel they belong. Similarly, the better the people know each other, the more likely they are to know each other's ability and talents and likewise what is expected of them to enhance quality teaching and learning in our schools.

Wong (2004) also reports that induction is a supporting process of professional growth which is organized by the school with the aim of supporting the new teachers during their first professional steps. The report goes to confirm that the new teachers are not ready and need guidance and support in facing the problems that appear during their initial steps. 
Furthermore, the need for induction is greatly felt when one considers Lordanides and Vryonis' (2003) assertion. Lordanides and Vryoni stated that the teaching profession, in comparison to other professions, is very complex and characterized by potential continuous anxiety, on both the personal and professional level, particularly during the first years.

It takes a longer time for a person to familiarize himself/herself to the organization norms and likewise the socio-economic settings of the place. They are therefore compelled to rely on hear-say from those already in the system than from the head since not properly inducted into the organization. I developed interest in this topic as a result of the continuous neglect of inducting teachers and office staff both new and old to their new environment. The phenomena carried out by the Municipal Education Directorate is by inviting only newly teachers and give them teaching and learning materials (TLMS) and them expected them to deliver at their various schools and in the municipality. Same is done at the school level where teaching and learning takes place thereby leaving the new entrant in a fix coupled with their accommodation, family and socioeconomic problems.

The character of new teachers' neglect of students is common in the West Mamprusi Municipality and these results in low performance. A critical observation of these is attributed to the effect of the perception of induction programs not organized in the Municipality and these has prompt me to extend my academic study works to find out on the effect of the perception of induction system in the West Mamprusi Municipality in the Northeast Region of Ghana.

Johnson and Kardos (2002), advocates for an induction model where new teachers are connected with the professional culture, in which they learn and develop professionally being guided both by their leaders and by other experienced teachers.

\section{Methodology}

The research was conducted in West Mamprusi Municipality with Walewale as its capital, in the Northeast Region of Ghana. The study investigated the induction system and its perception on public basic schools in the West Mamprusi Municipality in the Northeast Region. The targeted population was all the one hundred and twenty (120) head teachers and Assistant head teachers of the public basic schools in the West Mamprusi Municipal in the Northeast Region, made up of sixty (60) head teachers and sixty (60) assistant head teachers.

\section{Data Collection}

Purposive sampling was used to select all the 120 head teachers and Assistant head teachers for the study since they were professional who possessed the knowledge on induction system as they are supposed to conduct inductions in basic schools. Questionnaires were personally distributed to the 120 Head teachers and Assistant head teachers of public basic schools in the West Mamprusi Municipality of the Northeast Region. The researcher then visited the sampled population after which the questionnaires were administered on the 120 head teachers and assistant head teachers of the public basic schools sampled for the study in West Mamprusi Municipality. The respondents were given a two weeks grace period to fill the questionnaires before they were collected.

\section{Data Analysis}

Responses were then tabulated and analyzed using Statistical Package for Social Sciences (SPSS) technique. The researcher used frequencies, percentages, and tables to explain the responses from respondents. The percentages were used to analyze all the responses.

\section{Result and Discussion}

The demographic data of those who participated in this study is presented in Table1. 
Table 1: Demographic Characteristic of Respondents

\begin{tabular}{|l|l|l|}
\hline Variable & Frequency & Percentage \\
\hline Gender & 55 & \\
Male & 65 & 45.83 \\
\hline Total & 120 & 54.17 \\
\hline Age & & 100 \\
$24-34$ & 32 & \\
$35-45$ & 35 & 26.67 \\
$46-56$ & 26 & 29.16 \\
$56-66$ & 27 & 21.67 \\
\hline Total & 120 & 100 \\
\hline Qualification & & $\mathbf{2 2 . 5}$ \\
Diploma & 34 & $\mathbf{2 8 . 3}$ \\
Bachelor's Degree & 65 & 17.5 \\
Master's Degree & 21 & 100 \\
\hline Total & 120 & \\
\hline
\end{tabular}

Source: Field Data 2019

Table 1. Depicts the demographic characteristics of respondents and it shows out that majority of the respondents $(54.17 \%)$ were males while nearly two- fifth of the respondents $(45.83 \%)$ were females. This means that there were more male head teachers and assistant head teachers than female. Again, shows that majority of the head teachers and the assistant head teachers (26.67\%) were aged between 24-34 years, $29.16 \%$ were aged between 35-45 years while $21.67 \%$ were aged between $46-56$ years and $22.5 \%$ were aged between 56-66 years. It could be concluded that the majority of the head teachers and assistant head teachers were between the ages of 35-45 years and assumed that they have greater responsibilities at school. On respondents highest qualification, majority of the head teachers and assistant head teachers (54.2\%) were holders of the bachelor's degree, $17.5 \%$ were holders of the master's degree while $28.3 \%$ were holders of the diploma certificate.

Table 2: Respondents Opinion in the Organization of Training and Induction Programs in Basic Schools in the Study Area

\begin{tabular}{|c|c|c|c|c|}
\hline \multirow{2}{*}{ Statement } & \multicolumn{4}{|c|}{ Response N (\%) } \\
\hline & $\begin{array}{l}\text { Strongly } \\
\text { Agreed }\end{array}$ & Agreed & NeutralDisagreed & $\begin{array}{l}\text { Strongly } \\
\text { Disagreed }\end{array}$ \\
\hline $\begin{array}{ll}\text { - I support } & \text { the } \\
\text { introduction } & \text { of }\end{array}$ & $72(60)$ & 41(35) & $3(2) \quad 4(3.3)$ & - \\
\hline
\end{tabular}




\begin{tabular}{|c|c|c|c|c|c|}
\hline $\begin{array}{l}\text { induction programs in } \\
\text { schools. }\end{array}$ & & & & & \\
\hline $\begin{array}{l}\text { - An induction } \\
\text { program has greater } \\
\text { impact in Teaching. }\end{array}$ & $76(63)$ & $40(33)$ & $1(0.8)$ & $1(0.8)$ & $2(1.7)$ \\
\hline $\begin{array}{l}\text { - The non existence of } \\
\text { induction programs } \\
\text { are hindrance to the } \\
\text { development of our } \\
\text { schools. }\end{array}$ & $56(46.7)$ & $34(28.3)$ & 11(9) & $10(8)$ & $5(4)$ \\
\hline $\begin{array}{l}\text { - Induction programs } \\
\text { have an effect among } \\
\text { students in our } \\
\text { schools. }\end{array}$ & $61(50.8)$ & $49(40.8)$ & $9(7.5)$ & - & - \\
\hline $\begin{array}{l}\text { Induction programs } \\
\text { will lead to high yield } \\
\text { of results in our } \\
\text { schools. }\end{array}$ & $62(51.7)$ & $55(45.8)$ & - & - & $3(2.5)$ \\
\hline
\end{tabular}

Table 2: Depicts that more than half of the respondents (60\%) strongly agreed that they support the introduction of induction programs organized in basic schools in the study area, below half of the respondents (35\%) agreed while 2\% are neutral and only 3\% disagreed, which shows both head teachers and assistant head teachers support the introduction of induction programs in the West Mamprusi Municipality. Above $60 \%$ of the respondents strongly agreed that induction programs has greater impact in Teaching among basic schools in the study area, 33\% of the respondent agreed, while $0.8 \%$ are neutral, $0.8 \%$ disagreed and only $1.7 \%$ strongly agreed and therefore there is an indication that both head teachers and assistant head teachers assumed that induction programs has greater impact in Teaching within the West Mamprusi Municipality. Slightly below half of the respondents (46.7\%) strongly agreed that the non existence of induction programs are hindrance to the development of our schools in the study area, 28.3\% also agreed, $9 \%$ are neutral,8\% disagreed and 4\% strongly disagreed and this finally depicts that the nonexistence of induction programs are hindrance to the development of our schools within the West Mamprusi Municipality. Slightly half of the respondents (50.8\%) strongly agreed that induction programs have an effect among students in our schools, while $40.8 \%$ of the respondents agreed and only $7.5 \%$ stay neutral 
indicating that induction programs have an effect among students in our schools within the West Mamprusi Municipality. Finally more than half $(51.7 \%)$ of the respondents strongly agreed that induction programs leads to high yield of results in our schools, while $45.8 \%$ also agreed and $2.5 \%$ strongly disagreed depicting that induction programs will lead to high yield of results in our schools within the West Mamprusi Municipality.

Table 3: Respondents' Opinion on the level of satisfaction of induction programs organized in basic schools within the study area?

\begin{tabular}{|l|l|l|}
\hline Response & Frequency & Percentage \\
\hline Very effective & 32 & 26 \\
\hline Effective & 45 & 38 \\
\hline Somehow effective & 33 & 28 \\
\hline Not effective & 10 & 8 \\
\hline Total & 120 & 100 \\
\hline
\end{tabular}

Table 3: Shows that majority of the respondents are satisfied with the induction programs organized in basic schools in the study area are effective, slightly above one-fifth of the respondents also indicated induction programs organized in our schools are somehow effective, others too responded very effective with a close margin and only $10 \%$ of the respondents responded not effective indicating that induction head teachers and assistant head teachers are satisfied with the level of induction programs organized in our schools within the West Mamprusi Municipality.

Table 4: Respondents Opinion on the Causes of Ineffective Induction Programs in Basic Schools.

\begin{tabular}{|c|c|c|c|c|}
\hline \multirow[b]{2}{*}{ Statement } & \multicolumn{3}{|c|}{ Response N (\%) } & \multirow[b]{2}{*}{$\begin{array}{l}\text { Strongly } \\
\text { Disagreed }\end{array}$} \\
\hline & $\begin{array}{l}\text { Strongly } \\
\text { Agreed }\end{array}$ & Agree & $\begin{array}{l}\text { Neutral } \\
\text { Disagree }\end{array}$ & \\
\hline $\begin{array}{l}\text { Work overload is the cause } \\
\text { of the organization } \\
\text { induction programs in our } \\
\text { schools. }\end{array}$ & $42(51)$ & 34(41) & 6(7) & - \\
\hline $\begin{array}{l}\text { - Negative attitude to work is } \\
\text { a hindrance to induction } \\
\text { programs in our schools. }\end{array}$ & 32(39) & 24(29) & $\begin{array}{r}- \\
26(32)\end{array}$ & - \\
\hline $\begin{array}{l}\text { - Inadequate time is as a } \\
\text { result of ineffective } \\
\text { induction programs in our } \\
\text { schools. }\end{array}$ & 26(32) & 38(46) & $\begin{array}{r}- \\
18(22)\end{array}$ & - \\
\hline $\begin{array}{l}\text { - Lack of cooperation among } \\
\text { staff results in ineffective } \\
\text { induction programs. }\end{array}$ & 21(25) & 35(43) & $\begin{array}{c}- \\
26(32)\end{array}$ & - \\
\hline - Lack of induction policy & $43(52)$ & 32(39) & $7(8)$ & \\
\hline
\end{tabular}




\begin{tabular}{|l|l|l|l|l|}
\hline $\begin{array}{l}\text { blueprint in our schools } \\
\text { results in ineffective } \\
\text { induction programs. }\end{array}$ & & & & - \\
\hline $\begin{array}{l}\text { A financial constraint is a } \\
\text { challenge in organizing } \\
\text { induction programs in our } \\
\text { schools. }\end{array}$ & & $\mathbf{4 3 ( 5 2 )}$ & - & - \\
\hline
\end{tabular}

Table 4 depicts that slightly above half of the respondents (51\%) strongly agreed that work overload is one of the causes of ineffective training and induction, slightly above two-fifth of the respondents (41\%) agreed while $7 \%$ of the respondents disagreed which shows that work overload is a major cause of ineffective training and induction in basic schools in the study area. Almost two-fifth of the respondents (39\%) strongly agreed that negative attitude to work is a hindrance to ineffective training and induction programs, above one-quarter of the respondents (29\%) agreed while nearly one-third of the respondents (32\%) disagreed which shows that negative attitude is a hindrance to induction programs in basic schools within the study area. Just as the school has expectations and need, new teachers are not an exception and therefore may need modifying but the negative attitude of existing and beginning teachers is a serious hindrance. Again, almost one-third of the respondents $(32 \%)$ strongly agreed that Inadequate time is as a result of ineffective induction programs in our schools within the study area, above two-fifth of the respondents (46\%) agreed while slightly above one-fifth of the respondents (22\%) disagreed which shows that Inadequate time is as a result of ineffective induction programs in basic schools within the study area. The result is in line with Kumar (2000) that induction is a greatly neglected area of management policy which aims to maximize staff retention. One-quarter of the respondents $(25 \%)$ strongly agreed that lack of cooperation among members is one of the causes of ineffective training and induction, above two-fifth of the respondents (43\%) agreed while almost one-third of the respondents disagreed which shows that lack of cooperation among members is a major cause of ineffective training and induction in basic schools in the study area. Slightly above half of the respondents (52\%) strongly agreed that lack of induction policy blueprint is also a cause of ineffective training and induction, almost two-fifth of the respondents (39\%) agreed while $8 \%$ of the respondents disagreed which shows that lack of induction policy blueprint is another major cause of ineffective training and induction in basic schools in the study area. The result agrees with Middlewood and Lumby (2008) that there has not been any specific attempt to come out with a policy on induction. It therefore makes it difficult for educational leaders and school heads to conduct induction in the various educational institutions for a simple reason that there are no laid down parameters to be followed when conducting induction for staff members or employees of an organization. Hence, induction is loosely organized in many educational organizations. Besides, all the respondents (48\%) strongly agreed and 52\% agreed that financial constraints is one of the biggest cause of ineffective training and induction program within the study area, which shows that it is an issue for immediate attention. Indoshi (2003) stated that, induction of newly qualified teachers should be tailored according to beginning teachers' unique needs and this involves a lot of financial support.

Table 5: Respondents perception on Induction Programs on Teaching and Learning.

\begin{tabular}{|l|l|l|l|l|}
\hline \multirow{2}{*}{ Statement } & \multicolumn{3}{|c|}{ Response N (\%) } \\
\cline { 2 - 5 } & $\begin{array}{l}\text { Strongly } \\
\text { Agreed }\end{array}$ & Agreed & $\begin{array}{l}\text { Neutral } \\
\text { Disagreed }\end{array}$ & $\begin{array}{l}\text { Strongly } \\
\text { Disagreed }\end{array}$ \\
\hline
\end{tabular}




\begin{tabular}{|c|c|c|c|c|}
\hline $\begin{array}{l}\text { Improvement in professional } \\
\text { growth and development. }\end{array}$ & $35(43)$ & 47(57) & - & - \\
\hline $\begin{array}{l}\text { Effectively integrate new } \\
\text { employees to the organization. }\end{array}$ & 32(39) & 40(49) & $10(12)$ & - \\
\hline $\begin{array}{l}\text { Ensures maximum effectiveness } \\
\text { as quickly as possible. }\end{array}$ & 28(34) & $42(51)$ & 12(15) & - \\
\hline Maximizes teacher retention. & 45(55) & 37(45) & - & - \\
\hline $\begin{array}{l}\text { Promotes early collegiality among } \\
\text { teachers in a professional } \\
\text { community. }\end{array}$ & 39(48) & $37(45)$ & $6(7)$ & - \\
\hline $\begin{array}{l}\text { Ensures positive school climate } \\
\text { and culture. }\end{array}$ & 28(34) & $44(54)$ & $10(12)$ & \\
\hline $\begin{array}{l}\text { Provides new teachers with } \\
\text { training tools and TLMs. }\end{array}$ & $44(54)$ & $38(46)$ & - & - \\
\hline $\begin{array}{l}\text { Enables new employees to know } \\
\text { the terms and conditions of their } \\
\text { employment. }\end{array}$ & 31(38) & 33(40) & $12(15)$ & 6(7) \\
\hline
\end{tabular}

Table 5 shows that, all the respondents (100\%) strongly agreed that effectively organized training and induction programs improves professional growth and development which mean that improvement in professional growth is an effect of effectively organized training and induction program. Wong (2004); Gorton, Alston and Swowden (2005); Saphier et al (2001) and Wong (2004) indicated that induction is very relevant to every organization for the professional development or growth of their staff and also to ensure integration of staff as a family. Almost two-fifth of the respondents (39\%) strongly agreed that effectively organized training and induction program will integrate new employees to the organization; almost half of the respondents (49\%) agreed while12\%of the respondents disagreed which shows that effective organize induction program will integrate of new employees in our schools within the study area. The result corroborates Wong (2004) that induction programs therefore assist in reducing labor turnover by integrating new employees effectively into the organization. Again, slightly above one-third of the respondents (34\%) strongly agreed that effectively organized training and induction ensures maximum effectiveness as quickly as possible, slightly above half of the respondents (51\%) agreed while $15 \%$ of the respondents disagreed which shows that effectively organized training and induction ensures maximum effectiveness as quickly as possible. The result is in line with Pollard (2000) who emphasize that a newly employed teacher, even with a good knowledge of what the job entails, will need induction to ensure maximum effectiveness as quickly as possible in the school. The induction process can also serve as the starting point for the training and development of staff.

All the respondents (100\%) strongly agreed that effectively organized training and induction programs maximizes teacher retention which mean that improvement in professional growth is an effect of organized training and induction programs. The result is in support of Cobbold (2007) that one result of lack of induction and mentoring in current teacher education policy is that many newly qualified teachers feel neglected by the system. As one rural teacher put it, "They [GES] just post you and dump you here, that is all; nobody cares about you" There is no doubt that this practice does not foster in the new entrants any 
sense of belongingness to their profession. Instead, it breeds a sense of professional isolation and lack of commitment to work. It could be argued that this sense of seclusion and the short period of service (three years) which qualifies one for study leave with pay are major factors which lead to many teachers leaving for further studies. And their being away for that long period of three or four years exacerbates this isolation, making many such teachers discard the idea of coming back. After all, who would like to remain in a profession in which nobody appears to be their neighbor's keeper? Nearly half of the respondents $(48 \%)$ strongly agreed that effectively organized training and induction programs promotes early collegiality among teachers in a professional community, above two-fifth of the respondents (45\%) agreed, while $7 \%$ of the respondents disagreed which shows that effectively organized training and induction programs promotes early collegiality among teachers professional community. The result sustains Kelley (2004). That the induction process provides in a opportunities for new teachers to engage early in the collegial dialogue that is crucial to commitment, growth and effectiveness in one's profession. Induction pave the way for new teachers as an opportunities for them to collaborate with other teachers in professional communities, observe colleagues' classrooms, be observed by expert mentors, analyse their own practice, and network with other novice teachers (Darling-Hammond \& Sclan, 1996; Huling-Austin, 1992). Slightly above one-third of the respondents (34\%) strongly agreed that effectively organized training and induction programs ensures positive school climate and culture, above half of the respondents (54\%) agreed while $12 \%$ of the respondents disagreed which shows that effectively organized training and induction programs ensures positive school climate and culture within the study area. The result affirms Fullan (2001), Ingersoll (2002), Pantell (2011). Angelle (2006) and Wood (2005) that smooth inductions are best conducted effectively under positive school climate or culture, there by indicating that induction should not only just be conducted. It is important to consider the school atmosphere. Young (2007) likewise believe that the school culture contributes to new teachers' learning and professional growth, by their interaction both with the school staff and with the school leader. All the respondents (100\%) strongly agreed that effectively organized training and induction provides new teachers with training tools and other needs which mean that providing new teachers with training tools and other needs is an effect of effectively organized training and induction program. The result substantiates Pollard (2000) that successful integration depends on the time spent explaining the post and the systems used in the school. It is also an exercise that strengthens team-building. The tools and training made available to newcomers from the moment they arrive allow them to position themselves to integrate.

Finally, nearly two-fifth of the respondents (48\%) strongly agreed that effectively organized training and induction enables new employees to know the terms and conditions of their employment, two-fifth of the respondents $(40 \%)$ agreed, $15 \%$ of the respondents disagreed while $7 \%$ of the respondents strongly disagreed which shows that effectively organized training and induction programs enables new employees to know the terms and conditions of their employment. The new members of staff need to have basic information about their terms and condition of employment, immediate working environment. The result confirms Robertson (2003) that it is very important that a new employee gets to know the terms and condition of his employment so that he shall put his best effort in the line of growth. The introduction should be done to the work diligently in order to get the best out of him which will be beneficial to the company. As the responsibility of the human resource management, induction process is drawn in a planned way so that the new recruit shall be aware of everything about the company.

\section{Conclusion}

Based on the findings it can be concluded that induction programs supports and mitigates teacher attrition, increases career commitment, and contributes to retention through meeting teachers' personal and professional needs which also include improvement in professional growth and development, effective integration of new employees to the organization and providing new teachers with training tools and Other 
needs. Also working conditions play a significant role in teacher career satisfaction and commitment as the findings depicted.

Induction serves as a way of easing out the discomfort and allowing the employee concentrate in the friendly environment likewise understanding their roles, responsibilities and expectations of the organization they find themselves. The study found that these valuable reason for organizing induction and training is undermined by work overload of head teachers who are supposed to organize induction programs, negative attitude of existing staff as well as beginning teachers, management neglect of induction as a policy, lack of cooperation among members, lack of induction policy blueprint, financial constraints, negative school factor and hostile attitude of community members are some causes of ineffective training and induction programs and should be dealt with by educational authorities like the Ghana Education Service. Indeed, the importance of induction cannot also be compromised.

\section{References:}

1. Angelle, P.S. (2006). Instructional leadership and monitoring: Increasing teacher intent to stay through socialization. NASSP Bulletin, 90(4), 318-334.

2. Cobbold, C. (2007). Induction for teacher retention: A missing link in teacher education policy in Ghana. Post-Script: Postgraduate Journal of Education Research, 8(1), 7-8.

3. Darling-Hammond, L., \& Sclan, E. M. (1996). Who teaches and why: Dilemmas of building a profession for twenty-first century schools (2nd ed.). In J. Sikula (Ed.), Handbook of research on teacher education (pp.67-101). New York: Simon and Schuster.

4. Fullan, M. (2001). Leading in a culture of change. San Francisco, CA: Jossey-Bass.

5. Huling-Austin, L. (1992). Research on learning to teach: Implications for teacher induction and mentoring programs. Journal of Teacher Education, 43(3), 173-80.

6. Indoshi, F. C. (2003). Teachers' experiences of the probation period of teaching in Kenya: Implications for teacher induction policies and programmes. Journal of Inservice Education, 29(3), 234-258.

7. Ingersoll, R. (2002). The impact of mentoring on teacher retention: What the research says. Denver, CO: Education Commission of the States.

8. Johnson, S., \& Kardos, S. M. (2002). New teachers' experiences of mentoring: The good, the bad, and the inequity. Journal of Educational Change, 2, 12-32.Retrieved 30 November, 2015 from www.springerlink.com/index/n4255540p243v333.pdf

9. Kelley, L. M. (2004). Why induction matters. Journal of Teacher Education, 55(5), 438-448.

10. Kumar, P. B. S. (2000). The importance of induction in the organization. Victoria: University of Willington.

11. Lordanide, G., \& Vryonis, M. (2003). School Leaders and the Induction of New Teachers. ISEA,41,75-85.

12. Middlewood, D., \& Lumby, J. (2008). Human resource management in schools and colleges. London: Paul Chapman Publishing Limited.

13. Pantell, S. (2011).Seawater desalination in California. California: Coastal Commission.

14. Pollard, L. (2005).Induction guidelines for your new staff. New York: Simon and Schuster.

15. Robertson, J. (2003). The importance of staff induction. Retrieved on 17th March,2019 from http: //www.Steptwo.com.au/papers/cmb_Induction.

16. Saphier, J., Freedman, S., \& Aschheim, B. (2001). Beyond mentoring: How to nurture, support, and retain new teachers. Newton, MA: Teachers.

17. Wong, H.K. (2004). Induction programs that keep new teachers teaching and improving.NASSP Bulletin, 88(638), 41-58.

18. Wood, A. L. (2005). The Importance of principals: Site administrators' roles in teacher induction. American Secondary Education, 33(2), 39-62.

19. Youngs, P. (2007). District induction policy and new teachers' experiences: An examination of local policy implementation in Connecticut. Teachers College Record, 109(3), 797-837. 